Center

Confirmed

Meeting: GSA Annual Meeting in Denver, Colorado, USA - 25-28 Sep 2016

Session Type: Topical Sessions

Primary Selection: T185. Autogenic and Allogenic Controls and Morphodynamic Responses of Large Fluvial Fans (Fluvial Megafans)

Final Session Number:

Abstract Title: MEGAFANS—SOME NEW PERSPECTIVES FROM A GLOBAL STUDY

Preferred Presentation Format: Oral

Discipline Categories: Geomorphology Sediments, Clastic

Abstract Submission Fee: Paid (gsa-2016AM-7307-2001-9703-9159)

Presenting Author M. Justin Wilkinson

Texas State University

NASA/Johnson Space Center

601 University Drive

Geography Dept.

San Marcos, TX 78666

Phone Number: 281-483-5159 $281-483-5159$

Email: justin.wilkinson-1@nasa.gov

Student? N

T185. Autogenic and Allogenic Controls and Morphodynamic Responses of Large Fluvial Fans (Fluvial Megafans)

Jianqiao Wang, Andrew Leier

SEPM (Society for Sedimentary Geology); GSA Sedimentary Geology Division

Your confirmation number is: gsa-2016AM-7307-2001-9703-9159.

Or point your browser to /gsa/reminder.cgi to have that URL mailed to you again. Your username/password are Center.

\title{
MEGAFANS-SOME NEW PERSPECTIVES FROM A GLOBAL STUDY
}

WILKINSON, M. Justin, Geography Dept., Texas State University, NASA/Johnson Space Center, 601 University Drive, San Marcos, TX 78666, justin.wilkinson-1@nasa.gov A global study of megafans (>100 km long) has revealed their widespread existence on all continents, with almost 200 documented, 93 in Africa where research is most thorough. The largest measures $705 \mathrm{~km}$. Megafans are a major subset of "DFS" (distributive fluvial systems, a category that includes all fan-like features $>30 \mathrm{~km}$ long).

1. Many researchers now recognize megafans as different from floodplains, small coarsegrained alluvial fans, and deltas. Although smaller architectural elements in megafans are the 
same as those encountered in floodplains (channel, overbank, etc.), larger architectures differ because of the unconfined setting of megafans, versus the valley-confined setting of floodplains.

2. A length continuum is now documented between steep alluvial fans $10-20 \mathrm{~km}$ in length, and fluvial fans $30-50 \mathrm{~km}$ long. This implies a continuum of process from end-member alluvial fan processes (e.g. high-energy flows that emplace gravels, debris-flow units) to the relatively finegrained channel and overbank deposits common to purely fluvial fans. Combinations of these different processes will then occur in many mid-sized fans.

3. The global distribution suggests a prima facie relationship with tectonic environment rather than climatic zones, with local controls being the slope of the formative river and the existence of a basin subsiding below the long profile of the river. But the global population has revealed that most megafans are relict. So it is possible that further research will show relationships to prior climatic regimes.

4. Megafans can have regional importance: e.g., along the east flank of the central Andes, nested megafans total $~ 750,000 \mathrm{~km} 2$-and $1.2 \mathrm{~m} \mathrm{~km} 2$ if all megafans in S. America are counted. Modern megafan landscapes thus have basinal importance, orders of magnitude greater than alluvial fan bajadas.

5. Because so many aggrading basins are dominated today by DFS, it is claimed that DFS ought to be significant in the subsurface; and that existing fluvial models therefore may not apply to the majority of fluvial sedimentary units. Arguments have been raised against this view, but as modern megafan systems become better known they are rapidly being applied as a model in many fluvial basins. A small literature has arisen with apparent examples from every part of the world.

\section{Center \\ Center \\ Confirm \\ ed \\ Meeting:}

GSA Annual Meeting in Denver, Colorado, USA - 2016

Session Type:

Topical Sessions

Primary Selection:

T185. Autogenic and Allogenic Controls and Morphodynamic Responses of Large Fluvial Fans (Fluvial Megafans)

Final Session Number:

Abstract Title:

MEGAFANS—SOME NEW PERSPECTIVES FROM A GLOBAL STUDY

Preferred Presentation Format: 
Oral

Discipline Categories:

Geomorphology Sediments, Clastic

Abstract Submission Fee:

Paid (gsa-2016AM-7307-2001-9703-9159)

Presenting Author

M. Justin Wilkinson

Texas State University

NASA/Johnson Space Center

601 University Drive

Geography Dept.

San Marcos, TX 78666

Phone Number: 281-483-5159 $281-483-5159$

Email: justin.wilkinson-1@nasa.gov

Student? N

\section{https://gsa.confex.com}

Megafans—some new perspectives from a global study

A global study of megafans (>100 km long) has revealed their widespread existence on all continents, with almost 200 documented, 93 in Africa where research is most thorough.

The largest measures $705 \mathrm{~km}$. Megafans are a major subset of "DFS" (distributive fluvial systems, a category that includes all fan-like features $>30 \mathrm{~km}$ long).

1. Many researchers now recognize megafans as different from floodplains, small coarsegrained alluvial fans, and deltas. Although smaller architectural elements in megafans are the same as those encountered in floodplains (channel, overbank, etc.), larger architectures differ because of the unconfined setting of megafans, versus the valleyconfined setting of floodplains.

2. A length continuum is now documented between steep alluvial fans $10-20 \mathrm{~km}$ in length, and fluvial fans $30-50 \mathrm{~km}$ long. This implies a continuum of process from end-member alluvial fan processes (e.g. high-energy flows that emplace gravels, debris-flow units) to the relatively fine-grained channel and overbank deposits common to purely fluvial fans. Combinations of these different processes will then occur in many mid-sized fans.

3. The global distribution suggests a prima facie relationship with tectonic environment rather than climatic zones, with local controls being the slope of the formative river and the 
existence of a basin subsiding below the long profile of the river. But the global population has revealed that most megafans are relict. So it is possible that further research will show relationships to prior climatic regimes.

4. Megafans can have regional importance: e.g., along the east flank of the central Andes, nested megafans total $\sim 750,000 \mathrm{~km} 2$-and $1.2 \mathrm{~m} \mathrm{~km} 2$ if all megafans in S. America are counted. Modern megafan landscapes thus have basinal importance, orders of magnitude greater than alluvial fan bajadas.

5. Because so many aggrading basins are dominated today by DFS, it is claimed that DFS ought to be significant in the subsurface; and that existing fluvial models therefore may not apply to the majority of fluvial sedimentary units. Arguments have been raised against this view, but as modern megafan systems become better known they are rapidly being applied as a model in many fluvial basins. A small literature has arisen with apparent examples from every part of the world. 